\title{
PENDIDIKAN AGAMA ISLAM BERWAWASAN KEARIFAN LINGKUNGAN DI SEKOLAH DASAR: Dasar, Signifikansi dan Implementasi
}

\author{
Syamsul Kurniawan \\ IAIN Pontianak, Indonesia \\ syamsulkurniawan001@gmail.com
}

\begin{abstract}
If we agreed that human beings and their thoughts are the products of an educational process that they obtain, it can be said that the nature and behavior of humans that damage the environment are caused by the education that they got less optimal in strengthenig environmental wisdom. Because of that the lesson of Islamic Education should be able to be optimally given early for children, such as children of primary school. Environmental-oriented of Islamic Education needs to be given to students such as teaching them about the importance of caring for and preserving the environment and its functions. The focus of this paper is conceptual discussion of environmental oriented Islamic education in elementary schools concerning the basis, significance and implementation. Problem that want to be revealed through this paper: First, in Islam, what underlies the importance of Islamic education with environmental wisdom given to elementary school students? Second, why does Islam strongly emphasize the importance of strengthening environmental wisdom through Islamic education? Third, how should Islamic education with environmental wisdom given to elementary school students?
\end{abstract}

Keywords: Islamic Education, Environmental Wisdom and Elementary School.

\begin{abstract}
Abstrak: Jika kita menyetujui bahwa manusia dan pemikirannya adalah produk dari suatu proses pendidikan yang ia dapat, maka dapat dikatakan bahwa sifat dan perilaku manusia yang merusak lingkungan disebabkan karena pendidikan yang diterimanya tidak memaksimalkan usaha penguatan kearifan lingkungan. Karena itulah pelajaran Pendidikan Agama Islam seharusnya dapat secara optimal diberikan sejak dini pada anakanak, seperti pada anak-anak usia sekolah dasar. Pendidikan Agama Islam berwawasan lingkungan perlu diberikan pada siswa seperti mengajarkan pada mereka tentang pentingnya merawat dan melestarikan lingkungan beserta fungsi-fungsinya. Fokus tulisan ini adalah pembahasan secara konseptual tentang pendidikan agama Islam berwawasan lingkungan di Sekolah Dasar menyangkut dasar, signifikansi dan implementasinya. Pertanyaan yang ingin dijawab lewat tulisan ini, antara lain: Pertama, dalam Islam, apa yang mendasari pentingnya pendidikan agama Islam berwawasan kearifan lingkungan diberikan pada siswa sekolah dasar? Kedua, mengapa Islam sangat menekankan pentingnya penguatan kearifan lingkungan melalui pendidikan agama Islam? Ketiga, bagaimana pendidikan agama Islam berwawasan kearifan lingkungan sebaiknya diberikan pada siswa sekolah dasar?
\end{abstract}

Kata Kunci: Pendidikan Agama Islam, Kearifan Lingkungan dan Sekolah Dasar.

\section{A. Pendahuluan}

Krisis lingkungan sedang terjadi dan mengancam kehidupan manusia, hampir di seluruh belahan dunia. Krisis lingkungan yang terjadi semakin parah dan menjadi 
sebab terjadinya bencana juga menimpa belahan dunia Islam. Seperti polusi udara di Kairo dan Teheran, erosi di Yaman, dan penggundulan hutan di Banglades, Malaysia, dan juga Indonesia. ${ }^{24}$

Di Indonesia, perilaku masyarakat yang merusak pada lingkungan, seperti hutan, menyebabkan luas hutan semakin menyusut. Hutan kita ditebang jutaan hektar pada setiap tahunnya. Ini barangkali menjadi rekor penebangan hutan tercepat di dunia. Sementara, kita menyetujui bahwa hutan adalah paru-paru dunia dan bisa memberi kebaikan untuk manusia sedunia. Kecuali kerusakan hutan, juga terjadi krisis lingkungan seperti sampah, polusi udara, pemanasan global, pencemaran tanah, sungai tercemar, sulitnya mendapatkan air bersih, rusaknya ekosistem laut, dan abrasi adalah beberapa contoh lain yang bisa disebut. ${ }^{25}$

Meningkatnya kasus pengrusakan dan pencemaran lingkungan ini dianggap sebagai faktor utama terjadinya bencana seperti banjir, tanah longsor, kebakaran hutan dan lahan. Badan Nasional Penanggulangan Bencana (BNPB) mencatat sudah terjadi 513 bencana di tanah air, di antaranya banjir. Dampak bencana tersebut, ada 72 orang meninggal dunia dan hilang, 116 jiwa luka-luka, dan lebih dari 393 ribu mengungsi dan menderita. Sebanyak 12.104 rumah rusak meliputi 1.566 rumah rusak berat, 3.141 rumah rusak sedang dan 7.397 rumah rusak ringan. ${ }^{26}$

Kasus-kasus bencana yang terjadi di Indonesia terutama disebabkan karena perilaku masyarakat Indonesia yang seringkali merusak dalam pemanfaatan sumber daya alam (man made disaster). Konsekuensinya juga kembali pada manusia yang hidup di sekitar lingkungan yang dirusak, sehingga menjadi sengsara dan tidak sejahtera. Fakta pengrusakan dan pencemaran lingkungan jelas menjadi sangat ironi, manakala dikaitkan dengan statistik masyarakat Indonesia yang mayoritasnya beragama Islam.

\footnotetext{
${ }^{24}$ Zaim Saidi, "Islam Tradisional dan Krisis Lingkungan: Pandangan Seorang Aktifis," dalam Islamica, No. 3, March 1994, hlm. 19.

${ }^{25}$ Koran Sindo, "Survei Litbang Korban Sindo: 10 Problem Besar Lingkungan di Indonesia", Koran Sindo (Jakarta, Mei 2018), https:/ / nasional.sindonews.com/read/1302781/15/10-problem-besarlingkungan-di-indonesia-1525347778.

26 Jabbar Ramdhani, ‘513 Bencana Alam Terjadi di Indonesia Sejak Januari-Maret 2018', Detik News (3 Mar 2018), https://news.detik.com/berita/3895731/513-bencana-alam-terjadi-di-indonesiasejak-januari-maret-2018.
} 
Sebagaimana kita mafhumi, agama Islam amat menekankan pentingnya merawat dan menjaga kelestarian lingkungan. Merusak lingkungan berarti telah melanggar perintah Allah SWT tentang kearifan lingkungan. Sementara pelanggaran atas ketentuan Allah SWT, di antaranya melakukan pengrusakan terhadap lingkungan, mestilah berkonsekuensi buruk kepada pelakunya, baik langsung maupun tidak langsung. Dalam Al-Qur'an disebutkan: “Dan janganlah kamu membuat kerusakan di muka bumi, sesudah (Allah) memperbaikinya dan berdoalah kepada-Nya dengan rasa takut (Tidak akan diterima) dan harapan (akan dikabulkan). Sesungguhnya rahmat Allah amat dekat kepada orang-orang yang berbuat baik." (QS. al-A'raf [07]: 56). ${ }^{27}$

Kepribadian manusia dipengaruhi oleh pendidikan yang ia peroleh, baik dalam keluarga, sekolah, maupun di masyarakat. Maka, sangat mungkin sifat dan perilaku manusia yang doyan merusak lingkungan ini disebabkan karena pendidikan yang diperoleh olehnya kurang memerhatikan pentingnya kearifan lingkungan, terutama kearifan lingkungan yang berlandaskan ajaran agama yang ia anut. Bagi seorang muslim, pendidikan agama Islam untuk menguatkan kearifan lingkungan perlu diberikan sejak usia dini, seperti di Sekolah Dasar.

Terdapat beberapa tulisan yang membahas tema sejenis dengan tulisan ini, di antaranya tulisan Ali Usmar berjudul "Pendidikan Islam Berwawasan Lingkungan Hidup." Dalam tulisannya, Usmar mendefinisikan pendidikan berwawasan lingkungan hidup sebagai pendidikan yang menyadarkan siswa tentang posisi lingkungan hidup bagi mereka sebagai bagian dari umat manusia, sehingga dapat merekonstruksi satu pola pemahaman yang menganggap lingkungan sebagai objek yang tidak bisa diperlakukan semaunya pada satu bangunan paradigma yang menjadikan lingkungan sebagai satu bagian dari kehidupan yang butuh etika dan tatacara berinteraksi dengannya. Oleh karena itu, pendidikan berwawasan lingkungan memberikan bekal kepada siswa bagaimana tata cara berinteraksi dengan lingkungan menurut konsep Islam, dengan menggunakan metode sebagai tolak ukur penintegrasian, yaitu: pendekatan integratif, yaitu pendekatan yang didasarkan pemaduan mata pelajaran Pendidikan Lingkungan Hidup dengan mata pelajaran lain, sehingga outputnya terdapat pengaruh pengintegrasian pendidikan lingkungan 
hidup ke dalam mata pelajaran terhadap pengetahuan dan sikap siswa dalam pelestarian lingkungan. ${ }^{28}$

Tulisan Mawi Khusni Albar tentang, "Pendidikan Ekologi Sosial dalam Perspektif Islam: Jawaban terhadadap Krisis Kesadaran Ekologis", yang membahas kerangka konseptual pendidikan ekologi sosial dalam konteks pendidikan Islam dan meletakkannya sebagai jawaban pendidikan Islam dengan pendekatan pendidikan ekologi sosial terhadap persoalan lingkungan yang dihadapi manusia. Dua tema yang berupa pendidikan Islam dan pendidikan ekologi sosial menjadi pokok bahasan utama untuk ditarik sintesa yang berupa formulasi konseptual yang ideal untuk merespons persoalan lingkungan yang terjadi.

Diskursus pendidikan ekologi sosial dalam konteks pendidikan Islam diharapkan dapat memberikan kontribusi akademis maupun praksis bagi dunia pendidikan, khususnya pendidikan Islam. Secara konseptual, Mawi Khusni Albar mengusulkan empat konsep mendasar yaitu pengalaman hidup, ruang belajar, pengalaman paedagogis, agen dan partisipasi aktif. Pendidikan ekologi sosial dalam perspektif pendidikan Islam diharapkan akan memposisikan manusia dalam sintesis di antara humanisme dan ekosentrisme dalam perspektif ekologi. ${ }^{29}$

Kemudian tulisan Eha Julaeha dan Asep Kurniawan berjudul "Implementasi Pendidikan Agama Islam (PAI) Berwawasan Lingkungan di Sekolah Menengah Kejuruan Negeri I Indramayu." Dipaparkan oleh Eha Julaeha dan Asep Kurniawan bahwa penelitian mereka ini dilatarbelakangi oleh maraknya kerusakan lingkungan, banyaknya terjadi bencana alam yang merupakan ancaman yang membahayakan untuk makhluk di muka bumi ini. Oleh sebab itu, sangat penting adanya pendidikan berwawasan lingkungan yang diintegrasikan melalui pengelolaan pembelajaran pada semua mata pelajaran tak terkecuali mata pelajaran Pendidikan Agama Islam di lingkungan pendidikan formal untuk membentuk karakter peserta didik sebagai generasi yang sadar akan lingkungan hidup serta untuk menjaga kelestarian alam. Penelitian Eha Julaeha dan Asep Kurniawan ini bertujuan mendeskripsikan secara

28 Ali Usmar, "Pendidikan Islam Berwawasan Lingkungan", dalam An-Nahdhah, Vol. 8, No. 1 2014.

${ }^{29}$ Mawi Khusni Albar, "Pendidikan Ekologi Sosial dalam Perspektif Pendidikan Islam: Jawaban Terhadap Krisis Kesadaran Ekologis", dalam At-Tahrir, Vol. 17, No. 2, 2017. 
mendalam mengenai implementasi pembelajaran Pendidikan Agama Islam (PAI) berwawasan lingkungan hidup di SMK Negeri 1 Indramayu Kabupaten Indramayu.

Temuan penelitian menunjukan bahwa kebijakan pengelolaan pendidikan berwawasan lingkungan di SMK Negeri 1 Indramayu sudah diterapkan dengan baik sesuai dengan Standar Operasional Prosedur (SOP) Sekolah Adiwiyata. Pengelolaan pembelajaran Pendidikan Agama Islam (PAI) berwawasan lingkungan di SMK Negeri 1 Indramayu sudah mengarahkan aktivitas belajar peserta didik untuk ramah terhadap lingkungan. Implementasi pembelajaran PAI berwawasan lingkungan di SMK Negeri 1 Indramayu yang diberikan kepada peserta didik, yakni dengan membekali mereka dengan cara dan mengaplikasikannya dalam kehidupan keseharian include di dalamnya tentang penyadaran pentingnya lingkungan hidup. Faktor pendukung implementasi pembelajaran PAI berwawasan lingkungan di SMK Negeri 1 Indramayu antara lain lingkungan dan fasilitas sekolah yang mendukung dan terjalinnya sinergitas seluruh stakeholder sekolah dalam mewujudkan sekolah berwawasan lingkungan, sedangkan faktor penghambatnya antara lain waktu yang terbatas untuk jam tatap muka Pendidikan Agama Islam di sekolah. ${ }^{30}$

Tulisan-tulisan di atas meski membahas tema yang sejenis dengan tulisan ini, namun hakikatnya memiliki fokus yang berbeda. Fokus tulisan ini adalah pembahasan secara konseptual pendidikan agama Islam berwawasan lingkungan di Sekolah Dasar menyangkut dasar, signifikansi dan implementasinya. Pertanyaan yang ingin dijawab lewat tulisan ini, antara lain: Pertama, dalam Islam, apa yang mendasari pentingnya pendidikan agama Islam berwawasan kearifan lingkungan diberikan pada siswa sekolah dasar? Kedua, mengapa Islam sangat menekankan pentingnya penguatan kearifan lingkungan melalui pendidikan agama Islam? Ketiga, bagaimana pendidikan agama Islam berwawasan kearifan lingkungan sebaiknya diberikan pada siswa sekolah dasar?

30 Eha Julaeha and Asep Kurniawan, "Implementasi Pendidikan Agama Islam (PAI) Berwawasan Lingkungan di Sekolah Menengah Kejuruan Negeri I Indramayu," dalam Al-Tarbawi AlHaditsah 3, No. 2, 2018. 


\section{B. Dasar PAI Berwawasan Kearifan Lingkungan di Sekolah Dasar}

Kearifan lingkungan merupakan sebuah hal yang amat ditekankan dalam ajaran agama Islam. Dalam ajaran agama Islam, manusia adalah bagian dari alam, pengelola, dan khalifah (wakil Tuhan) di muka bumi. Hubungan antara manusia, alam, dan Tuhan digambarkan dalam bagan 1 sebagai berikut:

\section{Bagan 1}

\section{Hubungan antara Manusia, Tuhan, dan Alam (Lingkungan)}

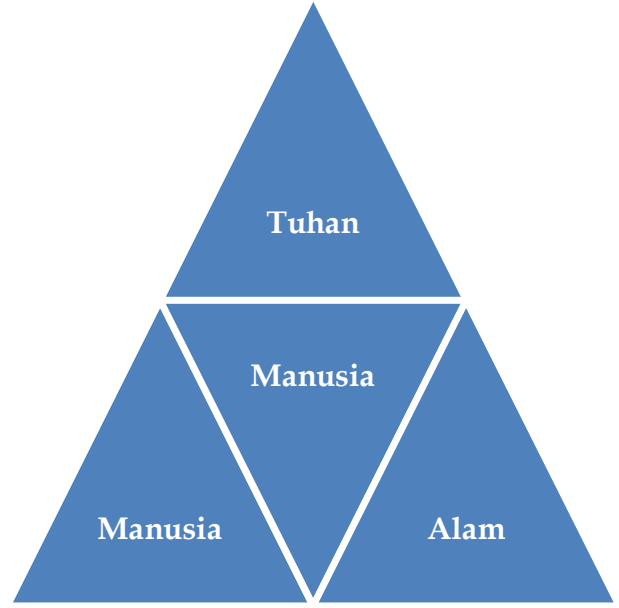

Sebagai khalifah di muka bumi, manusia tentu saja berhak memanfaatkan sumber daya alam untuk kesejahteraannya. Hal ini berlandaskan pada firman Allah Swt dalam Al-Qur'an yaitu: “Dan Dia telah menundukkan untukmu apa yang di langit dan apa yang di bumi semuanya, (sebagai rahmat) daripada-Nya. Sesungguhnya pada yang demikian itu benar-benar terdapat tanda-tanda (kekuasaan Allah) bagi kaum yang berpikir". (QS. al-Jatsiyah [45]: 13) $)^{31}$

Namun, manusia sebagai pengambil manfaat juga memiliki kewajiban dan mengemban tanggung jawab dari Tuhannya untuk merawat dan melestarikan lingkungannya, bukan justru mengambil langkah-langkah merusak dalam pemanfaatan lingkungan tersebut. Seruan ini dapat kita baca dari kasus kejatuhan Adam as. (Nabi sekaligus simbol manusia pertama) beserta istrinya Hawa ke muka bumi. Apa yang dialami Adam dan Hawa sampai diusir dari surga-Nya, karena tidak mengindahkan seruan-Nya mengenai kearifan ekologi. Adam dan Hawa mengikuti bujuk rayu syaitan. Adam dan Hawa mendekati pohon khuldi dan merusaknya.

${ }^{31}$ Departemen Agama RI, Al-Qur'an dan Terjemahan. 
Allah SWT berfirman yang artinya: “Dan Kami berfirman: "Hai Adam, diamilah oleh kamu dan isterimu surga ini, dan makanlah makanan-makanannya yang banyak lagi baik dimana saja yang kamu sukai, dan janganlah kamu dekati pohon ini, yang menyebabkan kamu Termasuk orang-orang yang zalim. Lalu keduanya digelincirkan oleh syaitan dari surga itu dan dikeluarkan dari keadaan semula dan Kami berfirman: "Turunlah kamu! sebagian kamu menjadi musuh bagi yang lain, dan bagi kamu ada tempat kediaman di bumi, dan kesenangan hidup sampai waktu yang ditentukan." Kemudian Adam menerima beberapa kalimat dari Tuhannya, Maka Allah menerima taubatnya. Sesungguhnya Allah Maha Penerima Taubat lagi Maha Penyayang. Kami berfirman: "Turunlah kamu semuanya dari surga itu! kemudian jika datang petunjuk-Ku kepadamu, maka barang siapa yang mengikuti petunjuk-Ku, niscaya tidak ada kekhawatiran atas mereka, dan tidak (pula) mereka bersedih hati". Adapun orangorang yang kafir dan mendustakan ayat-ayat Kami, mereka itu penghuni neraka; mereka kekal di dalamnya". (QS. al-Baqarah [02]: 35-39) 32

Bahkan dalam pandangan Al-Qur'an, krisis ekologi yang menimpa bumi ini erat kaitannya dengan krisis spiritual yang dialami manusia. Hal tersebut sebagaimana firman Allah yang artinya: "Telah nampak kerusakan di darat dan di laut disebabkan karena perbuatan tangan manusia, supaya Allah merasakan kepada mereka sebahagian dari (akibat) perbuatan mereka, agar mereka kembali (ke jalan yang benar)". (QS. ar-Ruum [30]: 41) 33

Sayangnya, ajaran paling purba yang diajarkan agama Islam tentang kearifan lingkungan ini tidak merembes menjadi living tradition dalam masyarakat Islam sesudah wafatnya Nabi. Pada hari ini, manusia sudah mulai jauh dari nilai-nilai ajaran agama, termasuk umat Islam, yang mana lingkungan tidak dilihat sebagai suatu bagian dari kemanusiaan, tetapi sesuatu di luar yang dapat dieksploitasi secara terusmenerus. ${ }^{34}$ Pada konteks ini, mesti dipahami bahwa sumber daya alam yang ada di lingkungan bukan milik manusia, tetapi ciptaan dan milik Tuhan. Manusia hanya dititipkan untuk merawat dan melestarikannya, serta boleh untuk menikmati dan

32 Ibid.

33 Ibid.

34 Syamsul Kurniawan, 'Tanah Airku Murka: Pentingnya Membangun Kesadaran Ekoteologi', Pontianak Post (Pontianak, Nopember 2006); Syamsul Kurniawan, 'Al-Qur'an dan Kesalehan Lingkungan', Pontianak Post, (Pontianak, Oktober 2007). 
memanfaatkan sumber daya alam yang telah disediakan tersebut secara bijaksana demi kesejahteraan hidup mereka.

Alam memiliki keseimbangan dan keteraturan (sunatullah) dan manusia diserahi tanggung jawab dalam menjaga keseimbangan dan keteraturan tersebutdengan dilandasi aqidah dan akhlaq terpuji. Maksudnya, manusia sebagai khalifah fi al-ard dalam melaksanakan tugasnya harus mengikuti petunjuk-petunjuk AlQur'an dan Sunnah Nabi SAW agar sesuai dengan apa yang dikehendaki oleh ajaran agama Islam. Pengembangan ilmu dan teknologi, hanya dibenarkan jika tidak merusak lingkungan, dan bersandar pada petunjuk-petunjuk Allah SWT baik dalam Al-Qur'an maupun Sunnah Nabi SAW. Kalau tidak, pengembangan ilmu dan teknologi berlangsung secara tidak terkendali, dan tidak akan mendatangkan ketenteraman, kenikmatan, apalagi kesejateraan. Malah justru berakibat terjadinya bencana di mana-mana yang mendatangkan penderitaan bagi umat manusia dan lingkungannya. ${ }^{35}$

Inilah yang mendasari pentingnya kearifan lingkungan yang berlandaskan ajaran agama dididikkan melalui pendidikan agama Islam, sejak dini pada anak-anak, termasuk anak-anak yang sedang mengenyam pendidikan sekolah dasar.

\section{Signifikansi PAI Berwawasan Kearifan Lingkungan di Sekolah Dasar}

Signifikansi kearifan lingkungan diajarkan melalui pendidikan agama Islam, di antaranya berlandaskan pada argumen sebagai berikut. Pertama, menjaga alam sama saja dengan menjaga agama, menjalankan perintah Allah untuk berlaku adil, dan berbuat kebajikan. "Dan janganlah kamu membuat kerusakan di muka bumi, sesudah (Allah) memperbaikinya dan berdoalah kepada-Nya dengan rasa takut (tidak akan diterima) dan harapan (akan dikabulkan). Sesungguhnya rahmat Allah amat dekat kepada orang-orang yang berbuat baik." (QS. Al-A'raf [07]: 56). ${ }^{36}$

Kedua, menjaga alam sama dengan menjaga jiwa, perlindungan terhadap kehidupan dan keselamatan mereka. "Oleh karena itu Kami tetapkan (suatu hukum) bagi Bani Israil, bahwa: barangsiapa yang membunuh seorang manusia, bukan karena orang itu (membunuh) orang lain, atau bukan karena membuat kerusakan dimuka bumi, maka seakan-

\footnotetext{
${ }^{35}$ Ahmad Baiquni, ‘Tugas Ganda Manusia', in Iqra' (Yogyakarta: Salahuddin Press, 1985).

${ }^{36}$ Departemen Agama RI, Al-Qur'an dan Terjemahan.
} 
akan dia telah membunuh manusia seluruhnya. Dan barangsiapa yang memelihara kehidupan seorang manusia, maka seolah-olah dia telah memelihara kehidupan manusia semuanya. Dan sesungguhnya telah datang kepada mereka rasul-rasul Kami dengan (membawa) keteranganketerangan yang jelas, kemudian banyak diantara mereka sesudah itu sungguh-sungguh melampaui batas dalam berbuat kerusakan dimuka bumi". (QS. Al-Maidah [05]: 32) ${ }^{37}$ Dalam ajaran agama Islam, kasus pembunuhan terhadap jiwa sebagai sebuah dosa besar, pun terlarang untuk membunuh diri sendiri. Bukankah rusaknya lingkungan hidup dapat berdampak buruk bagi penjagaan kesehatan manusia, korban banjir, longsor, penyakit akibat polusi udara, air, makanan, dan lain-lain yang dapat berdampak buruk bagi kehidupan manusia.

Ketiga, merawat lingkungan termasuk upaya menjaga kualitas keberlangsungan hidup keturunan kita di masa yang akan datang. Hal ini sejalan dengan maksud sebuah hadits: "Sesungguhnya jika kamu meninggalkan anak-anakmu dalam keadaan kaya, itu lebih baik daripada meninggalkan mereka dalam keadaan miskin dan meminta-minta pada orang lain." (HR Bukhari dan Muslim). Contohnya ialah hemat air dan menjaga sumber air agar tidak tercemar merupakan upaya menjaga ketersediaan air bersih bagi generasi yang akan datang. Kita tidak dapat membayangkan masa depan manusia tanpa kecukupan air bersih. Bisa jadi negara-negara akan berperang memperebutkan sumber air bersih karena kelangkaannya. Hari ini di sebagian belahan bumi saja sudah banyak manusia sulit mendapatkan air bersih.

Keempat, merawat lingkungan sama dengan menjaga akal. Keberadaan lingkungan yang baik, udara yang bersih, akan membantu perkembangan otak dengan baik. Sebaliknya lingkungan yang tidak sehat dan udara yang tercemar dapat menurunkan kualitas kecerdasan seorang anak.

Kelima, menjaga alam berarti menjaga harta. Allah SWT menjadikan alam semesta sebagai harta bekal kehidupan manusia di atas muka bumi. Bumi, pohon, binatang, air, sumber energi, dan lain-lain adalah harta. Pengrusakan lingkungan berarti merusak modal kehidupan manusia yang telah diberikan Allah.

Selain itu, signifikansi dari pendidikan agama Islam berwawasan kearifan lingkungan ini hakikatnya tergambarkan dalam ajaran agama Islam yang dibawa oleh 
Nabi Muhammad SAW, sebagaimana berikut: Pertama, tentang dampak polusi atau pencemaran udara serta ruang hijau. Dapat dimafhumi, apabila udara tidak melingkupi seluruh permukaan bumi, begitu satu bagian dari permukaan bumi kehilangan sinar matahati, maka bagian ini akan segera mengalami penurunan suhu udara hingga 160 derajat dibawah nol, di mana hawa dingin tak tertahankan ini akan segera memusnahkan seluruh eksistensi hidup, karena pada prinsipnya, udara berfungsi untuk menghalangi bumi dalam mempertahankan hawa panas yang diperolehnya dari matahari. Selain itu manusia membutuhkan oksigen untuk kelangsungan hidupnya, dan kebutuhan yang diperlukannya melalui pernafasan ini akan terpenuhi dengan adanya hawa yang bersih dan sehat, oleh karena itu memanfaatkan udara yang bersih dan sehat merupakan salah satu dari kebutuhan primer manusia.

Namun dari sisi yang lain, perkembangan teknologi dan modernitas kehidupan masyarakat, demikian juga urgensi penciptaan fasilitas-fasilitas baru perkotaan untuk menjawab kebutuhan masyarakat kota yang semakin hari semakin berkembang, telah membuat tingkat pencemaran udara semakin tinggi dan secara bertahap kita menyaksikan juga semakin berkurangnya ruang hijau perkotaan serta terjadinya pencemaran lingkungan hidup. Dikarenakan kelangsungan generasi dan masyarakat manusia bergantung pada kesehatan dan keselamatan masyarakat, maka dengan melarang hal-hal yang buruk dan tercela serta menghalalkan kesucian dan kebersihan. Islam telah mempersiapkan jalan untuk mencapai tujuan dan sasaran ini, dan hal inilah yang harus dipahami oleh seorang anak, seperti anak-anak usia Sekolah Dasar.

Iklim perkotaan saat ini telah mengalami perubahan yang yang mencolok dibawah pengaruh kepadatan dan keterpusatan kegiatan-kegiatan kota di mana pengkajian wilayah-wilayah kota akan ditinjau secara tertentu dan terpisah dari iklim wilayah, seperti pengaruh-pengaruh yang ditimbulkan melalui kurangnya ruang hijau perkotaan terhadap ekologi kota terutama dalam kaitannya dengan iklim udara, tanah, air bawah tanah dan lain-lain, sedemikian berpengaruh sehingga unsur-unsur pembentuk dan konstruktifnya benar-benar mengalami perubahan di lingkungan perkotaan. 
Meskipun masalah ruang hijau perkotaan ini tidak dijabarkan dalam bentuk yang khas dan kekinian dalam teks-teks dan literatur-literatur utama agama kita, akan tetapi topik ini berada dibawah subyek yang lebih universal, seperti penanaman pohon, mendorong masyarakat untuk melakukan penghijauan dan melarang penebangan pepohonan, dimana hal ini menghikayatkan kepedulian dan perhatian agama Islam terhadap masalah ini.

Dalam kaitannya dengan masalah ini Nabi Muhammad Saw dalam salah satu hadisnya bersabda, "Jika kiamat telah tiba dan terdapat sebuah tunas di tangan salah satu kalian, maka tanamlah tunas tersebut jika mampu." Dalam melarang dan menegur mereka yang menebangi pepohonan dan menghancurkan sumber-sumber daya alam serta lingkungan hidup, Nabi Muhammad Saw bersaba, "Siapapun yang memotong pohon Sadr, maka ia akan terpuruk ke dalam api jahannam." 38 Pohon sidrah adalah pohon yang terkenal dengan sebutan al-sidr, yang biasanya tumbuh di padang pasir, tahan terhadap panas dan tidak memerlukan air. Pohon tersebut banyak digunakan sebagai tempat berteduh oleh para musafir, orang yang mencari lahan peternakan, pengembala, dan juga orang lain mempunyai tujuan tertentu.

Ancaman neraka bagi orang yang memotong pohon sidrah menunjukkan perlunya menjaga kelestarian lingkungan alam. Karena keseimbangan antara makhluk satu dengan lainnya perlu dijaga, sedangkan perbutan memotong pohon sidrah adalah salah satu bentuk perbuatan yang mengancam unsur-unsur alam yang sangat penting untuk keselamatan hidup manusia dan makhluk hidup lainnya.

Sebagian ulama hadits menyalah artikan hadits diatas, dengan menakwilkan hadits tersebut dengan mengatakan bahwa yang dimaksud pohon sidrah adalah yang tumbuh di kawasan Tanah Haram. Seolah-olah mereka menganggap terlalu berlebihannya bentuk hukuman api neraka bagi perbuatan sekedar menebang pohon. Dalam hal ini, menarik untuk diungkap bahwa Abu Daud memiliki pengertian tepat mengenai hadits tersebut. Beliau pernah ditanya tentangnya, dan menjawab, "Barangsiapa menebang pohon Sidrah di padang sahara yang dipakai untu berteduh oleh

38 Al-Imam Al-Hafizh Abu Sulaiman Al-Asy'ats Al-Sijistani Abu Dawud, Sunan Abu Dawud, Vol. 1, (Beirut: Dar al-Kutub Al-'Ilmiyyah, 1996). 
musafir dan binatang ternak, dengan tanpa tujuan yang dapat dibenarkan dan dengan unsur kesengajaan serta zhalim, maka Allah akan meluruskan kepalanya ke dalam api neraka." 39

Penghijauan merupakan aspek penting yang tidak dapat ditinggalkan pandangan agama Islam tentang kearifan lingkungan. Perhatian sunnah Nabi terhadap upaya-upaya penghijauan ini sangatlah besar. Hadits Nabi SAW mengkategorikan penanaman pohon sebagai perbuatan yang sangat mulia dan menjadikannya sebagai salah satu cara yang utama dalam mendekatkan diri kepada Allah SWT. Sebab, bila pohon itu dapat dimanfaatkan oleh orang lain, oleh burung atau binatang ternak, perbuatan itu akan dicatat sebagai sedekah jariyah yang pahalanya terus mengalir.

Berkaitan dengan ini, Imam Muslim meriwayatkan dari Jabir RA, bahwa Rasulullah SAW bersabda: "Barang siapa di antara orang Islam yang menanam tanaman maka hasil tanamannya yang dimakan akan menjadi sedekahnya, dan hasil tanaman yang dicuri akan menjadi sedekahnya. Dan barangsiapa yang merusak tanamannya, maka akan menjadi sedekahnya sampai hari kiamat."

Pada konteks ini seorang siswa dapat dipahamkan sejak dini bahwa merusak dan menghancurkan segala sesuatu yang termasuk dalam sumber daya nasional bisa dikatakan tidak sesuai syar'i. Selain di dunia tempat kita hidup, terdapat ribuan faktorfaktor penting lainnya yang saling bekerjasama supaya manusia bisa memperoleh manfaat. Ketiadaan salah satu dari mereka ini akan memperhadapkan manusia pada berbagai dilema kehidupan yang sangat serius. Allah SWT telah menciptakan kenikmatan-kenikmatan di dunia dalam bentuk makanan, minuman dan segala yang memberikan kesejahteraan dan kenyamanan hidup bagi manusia dan berdasarkan ajaran-ajaran Al-Qur'an manusia tidak dilarang untuk memanfaatkan dan merasakan kenikmatan-kenikmatan hidup tersebut, akan tetapi mereka dilarang dari menyianyiakan, merusak dan memanfaatkannya secara tidak tepat. "Hai anak Adam, pakailah pakaianmu yang indah di setiap (memasuki) masjid, makan dan minumlah, dan jangan berlebih-lebihan. Sesungguhnya Allah tidak menyukai orang-orang yang berlebih-lebihan." (QS. Al- A'raf [07]: 31) ${ }^{40}$

\footnotetext{
39 Ibid.

40 Departemen Agama RI, Al-Qur'an dan Terjemahan.
} 
Kedua, dampak limbah. Persoalan penting menjaga kebersihan lingkungan hidup merupakan salah satu topik yang sangat serius dan asasi bagi masyarakat saat ini. Jika menjaga lingkungan hidup tidak dianggap sebagai kewajiban umum, tidak dianggap secara serius oleh warga, siapapun bisa mencemari lingkungan hidup, atau limbah serta sampah-sampah tidak dikumpulkan dengan metode yang benar dan sehat, maka limbah dan sampah akan menjadi faktor pencemar lingkungan hidup dan pembawa bencana bagi keselamatan masyarakat.

Sampah dan limbah-limbah menyimpan berbagai mikroba dan menjadi tempat perkembangbiakan serangga serta berbagai sumber penyakit. Oleh karena itu Nabi Muhammad Saw dalam salah sebuah hadisnya bersabda, "Jangan menyimpan sampah di dalam rumah pada malam hari, melainkan keluarkan sampah-sampah tersebut pada siang hari, karena sampah merupakan tempat berkumpulnya syaitan." Demikian juga Nabi Muhammad SAW bersabda, "Jangan mengumpulkan tanah di belakang pintu (halaman), karena akan menjadi sarang setan." Adakah yang dimaksud dengan syaitan di sini adalah tempat berkumpulnya bakteri-bakteri yang membahayakan, tempat perpindahan dan perkembangbiakan berbagai macam penyakit?

Dalam sirah dan metode kehidupan Rasulullah SAW dan para sahabatnya, banyak kita saksikan penekanan beliau terhadap kebersihan dan menyarankan hal ini kepada para pengikutnya. Kewajiban menghindari kotoran manusia dan kenajisannya ketika bersentuhan dengannya serta kewajiban bersuci dan mencuci segala sesuatu yang terkotori olehnya, merupakan salah satu layanan ilmiah yang diberikan oleh agama Islam kepada manusia yang menciptakan kebersihan lingkungan hidup dari pencemaran dan hal-hal yang najis. Saat ini kotoran manusia dianggap sebagai pemicu utama dari mayoritas penyakit-penyakit mikroba dan cacing seperti kolera dan penyakit-penyakit yang dikenal dengan parasit usus pencernaan yang disebabkan oleh mikroba dan cacing.

Ali bin Abi Thalib as berkata, “Nabi Muhammad Saw melarang membuang kotoran besar di tepian air yang mengalir, di dekat mata air yang jernih dan di bawah pepohonan yang berbuah." Demikian juga dalam riwayat yang lain dikatakan, "Nabi Muhammad SAW melarang manusia membuang air kecil di bawah pepohonan yang berbuah, di halaman atau di atas air yang tergenang." 
Pada konteks ini, seorang siswa Sekolah Dasar perlu diajarkan tentang bagaimana perkembangan inovasi, urbanisasi dan meningkatnya konsumerisasi pada masyarakat perkotaan, pada setiap harinya akan dihasilkan ribuan ton sampah dimana pengumpulan dan penimbunan serta pembuangannya yang dilakukan dengan benar dan sehat merupakan hal terpenting dari masalah kesehatan yang perlu mendapatkan perhatian lebih banyak.

Dalam ajaran agama Islam dan bahkan pada agama-agama yang lain, jiwa manusia dianggap memiliki nilai tinggi dan menjaganya merupakan tidakan yang wajib. Dengan alasan inilah sehingga banyak ayat al-Qur'an yang menekankan bagi seseorang untuk tidak melakukan tindakan-tindakan yang akan menyebabkan kehancuran diri mereka sendiri.

Oleh karena itu, seorang siswa sekolah dasar harus dipahamkan bahwa agama yang ia anut tidak memberikan kebolehan kepada siapapun untuk mencemari lingkungan hidupnya dan selainnya, baik dengan tindakan maupun perbuatannya, tidak boleh acuh tak acuh terhadap persoalan-persoalan yang berkaitan dengan unsur terpenting kesehatan, dan tidak berhak menghilangkan peluang masyarakat dalam memperoleh kehidupan yang sehat dengan ketidak pedulian terhadap lingkungan sosial.

Ketiga, pemeliharaan flora dan fauna. Saat ini ada kecenderungan manusia melakukan perbuatan destruktif pada alam, termasuk melakukan pengrusakan pada flora dan fauna, akibatnya sejumlah hewan mulai mengalami kepunahan, ekosistem orang utan, enggang gading, burung cenderawasih, dan lain-lain sudah sangatlah kritis. Akibatnya terasa, betapa ekosistem yang seimbang menjadi tidak seimbang lagi. Beberapa waktu lalu di Jawa Timur misalnya, wabah ulat bulu menyerang warga, wabah tom cat, dan lain adalah bukti dari kecenderungan ini.

Dalam QS. Ar-Rum (30): 41, Allah SWT sudah mengingatkan kita umat manusia, supaya sadar dan lebih memperhatikan kualitas lingkungan hidupnya. “Telah timbul kerusakan di darat dan laut disebabkan perbuatan tangan manusia, supaya Allah merasakan kepada mereka, sebagian dari (akibat) perbuatan mereka, agar mereka kembali (ke jalan yang benar)." (QS. Ar-Ruum [30]: 41) ${ }^{41}$ 
Manusia diciptakan oleh Allah tujuannya adalah untuk menjadi khalifah di muka bumi, yang tentunya juga harus dapat melestarikan bumi ini. Memang suatu saat nanti kiamat pun akan terjadi. Namun, jika manusia terus bersikap merusak lingkungan seperti ini, maka tentunya kiamat itu sendiri akan menjadi lebih cepat karena ulah manusia itu sendiri. Setidaknya kita sebagai seorang muslim, dapat melestarikan lingkungan karena tentunya kita telah mengetahui mana yang baik dan mana yang buruk.

Dalam konteks inilah, seorang siswa Sekolah Dasar harus memahami posisinya sebagai umat Islam yang harus selalu sadar untuk memelihara kelestarian lingkungan hidup, menjaga dan memanfaatkan alam terutama flora dan fauna, yang sengaja diciptakan oleh Allah untuk kepentingan manusia, dengan catatan kita juga harus sayang kepada flora dan fauna sebagai sesama makhluk hidup, seperti yang diisyaratkan QS.. Al- Baqarah: 22 atau pada QS.. Al Baqarah: 27. “Dialah yang menjadikan bumi sebagai hamparan bagimu dan langit sebagai atap, dan Dia menurunkan air (hujan) dari langit, lalu Dia menghasilkan dengan hujan itu segala buah-buahan sebagai rezeki untukmu; karena itu janganlah kamu mengadakan sekutu-sekutu bagi Allah, padahal kamu mengetahui.” (QS. Al-Baqarah [02]: 22); “(yaitu) orang-orang yang melanggar perjanjian Allah sesudah perjanjian itu teguh, dan memutuskan apa yang diperintahkan Allah (kepada mereka) untuk menghubungkannya dan membuat kerusakan di muka bumi. Mereka itulah orang-orang yang rugi." (QS. Al-Baqarah [02]: 27). ${ }^{42}$

Flora dan fauna sangatlah penting keberadaannya bagi manusia, dan ini harus dipahamkan betul pada seorang siswa sekolah dasar melalui pendidikan agama Islam yang diberikan pada mereka, sehingga mereka dengan sadar dan terbiasa melestarikan dan menjaga kelangsungan flora dan fauna.

\section{Implementasi PAI Berwawasan Kearifan Lingkungan di Sekolah Dasar}

Islam merupakan agama yang berisi ajaran dan petunjuk serta pedoman bagi para pemeluknya tentang bagaimana manusia harus bersikap dan berprilaku dalam kehidupan. Petunjuk dan pedoman ini secara sempurna telah digariskan oleh ajaran Islam dalam kitab suci Nya, Al-Qur'an dan hadits-hadits Nabi SAW. Petunjuk ini 
mengatur manusia bagaimana harus hidup bahagia dan sejahtera, didunia dan di akhirat. Di samping itu, petunjuk ini juga mengatur hubungan manusia dengan Allah SWT, Sang Penciptanya, hubungan manusia dengan manusia lainnya, dan manusia dengan alam semesta termasuk bumi yang dianugerahkan oleh Tuhan Yang Maha Pemurah dan Pengasih bagi kesejahteraan hidupnya. Karenanya, Islam secara jelas mengajarkan tanggung jawab manusia bagi kelangsungan hidup dan kesejahteraan makhluk hidup lainnya. Pendidikan Agama Islam Berwawasan lingkungan, yakni pendidikan agama Islam yang berhubungan dengan pengetahuan lingkungan di sekitar manusia dengan berbagai unsurnya, memiliki posisi penting dalam rangka menjaga keserasian dan kelangsungan lingkungan hidup itu sendiri.

Sekolah merupakan salah satu komponen yang juga berperan penting dalam membangun karakter dari seorang anak, di samping keluarga dan masyarakat, termasuk kearifan lingkungan. Sebagaimana dimafhumi, kearifan lingkungan merupakan salah satu di antara 18 karakter yang disarankan oleh Kementerian Pendidikan dan Kebudayaan (Kemendikbud). ${ }^{43}$ Pendidikan agama Islam yang diberikan pada siswa di Sekolah Dasar punya andil dalam menguatkan karakter cinta lingkungan, sehingga menjadikan mereka kelak sebagai pribadi-pribadi yang bersikap arif pada lingkungannya.

Menurut Rustam, pendidikan agama Islam sudah memang seharusnya memberikan kesempatan pada siswa untuk menerima, merespons, dan menginisiasi perubahan melalui inovasi dan rasa tanggung jawab. ${ }^{44}$ Agama Islam tidak akan dihayati dan diamalkan seseorang kalau hanya diajarkan saja, tetapi harus dididik melalui proses pendidikan yang Islami, termasuk kaitannya dengan kearifan lingkungan. Dari segi lainnya pendidikan agama Islam yang berwawasan kearifan lingkungan ini seharusnya tidak bersifat teoritis saja, tetapi juga praksis, karena ajaran agama Islam tidak memisahkan antara iman dan amal saleh. Sesuai dengan maksud sebuah hadits, "Sesempurna-sempurnanya iman seseorang adalah yang paling baik akhlaknya." (HR Abu Dawud dan Atturmudzi)

43 Syamsul Kurniawan, Pendidikan Karakter: Konsepsi \& Implementasinya Secara Terpadu di Lingkungan Keluarga, Sekolah, Perguruan Tinggi dan Masyarakat, (Yogyakarta: Ar-Ruzz Media, 2013).

${ }_{44}$ Rustam, "Integrasi Pendidikan Karakter dalam Pendidikan Islam", dalam At-Turats, Vol. 6, No. 1, 2012. 
Pada konteks demikian, pendidikan agama Islam hendaknya dapat mendidik siswa-siswa Sekolah Dasar dalam rangka membangun kepribadian beriman dan bertaqwa, sehingga menyadari kedudukan, tugas, dan fungsinya di dunia dengan selalu memelihara hubungan baik dengan Allah SWT, dirinya sendiri, masyarakat, dan alam (lingkungan)nya. Pendidikan agama Islam mempunyai pengertian sebagai usaha sadar atau kegiatan yang disengaja dilakukan untuk membimbing, dan sekaligus mengarahkan siswa pada kepribadian yang utama berdasarkan nilai-nilai etika Islami dengan tetap memelihara hubungan baik dengan Allah SWT, hubungan baik dengan sesama manusia, dan hubungan baik dengan alam.

Dengan demikian, salah satu di antara tujuan pendidikan agama Islam adalah membangun kesadaran siswa Sekolah Dasar tentang pentingnya membangun hubungan baik dengan alam berdasarkan motivasi keagamaan (kearifan lingkungan). Dalam hal ini, pendidikan agama Islam yang berwawasan kearifan lingkungan mesti didesain dengan baik untuk kepentingan tersebut dan bisa diimplementasikan.

Setidaknya, ada empat komponen yang mesti diperhatikan dalam pengimplementasiannya: pertama, tujuan pembelajaran; kedua, materi atau bahan ajar; ketiga, metode mengajar; dan keempat, evaluasi pembelajaran. Kesemua komponen ini mesti dipertimbangkan dalam merumuskan model kurikulum yang tepat dan penyediaan sarana prasarana yang mendukung. Harapannya setelah siswa menerima pelajaran pendidikan agama Islam, siswa mengalami perubahan, seperti menjadi lebih arif pada lingkungannya.

Pendidikan agama Islam yang berwawasan lingkungan sebagaimana yang dimaksud pada tulisan ini adalah upaya pengimplementasian nilai-nilai Islam dalam keseluruhan proses pembelajaran Pendidikan Agama Islam untuk mencapai sebuah tujuan tertentu, yaitu menguatkan kearifan lingkungan. Nilai-nilai Islam tersebut diambil dari sumber dan dasar ajaran agama Islam, sebagaimana termuat pada AlQur'an dan As-Sunnah.45 Berdasarkan pengertian ini, pendidikan agama Islam yang diberikan pada siswa Sekolah Dasar dalam rangka menguatkan kearifan lingkungan mesti bersumber pada Al-Qur'an dan As-Sunnah. hlm. 23.

45 Syamsul Kurniawan, 'Pendidikan Menurut Al-Ghazali', dalam At-Turats, Vol. 3, No. 1, 2008, 
Tujuan pendidikan yang merupakan masalah inti dalam pendidikan, juga penting dirumuskan secara tepat. Pendidikan sebagai usaha pasti mengalami permulaan dan kesudahan. Adapula usaha terhenti karena suatu kendala sebelum mencapai tujuan, tetapi usaha itu belum dapat disebut berakhir. Pada umumnya, suatu usaha baru dapat disebut berakhir jika tujuan akhir telah tercapai.

Tujuan pendidikan agama Islam hendaknya mengarah pada realisasi orientasi keagamaan dan akhlak, dengan titik penekanannya pada perolehan keutamaan dan taqarrub kepada Allah (Ramayulis dan Nizar, 2009: 273). ${ }^{46}$ Hal ini sejalan dengan pendapat al-Ghazali, bahwa orientasi pendidikan adalah menggapai ridha Allah. ${ }^{47}$ Firman Allah SWT dalam QS. adz-Dzariyat: 56: “Tidaklah Aku ciptakan jin dan manusia melainkan agar beribadah kepada-Ku." 48 Ayat ini berlaku pada semua hal yang dikerjakan manusia, termasuk dalam pendidikan agama Islam, mesti dalam rangka taqarrub kepada Allah. Jika yang dimaksud adalah pendidikan agama Islam yang berwawasan kearifan lingkungan, mestinya siswa-siswa Sekolah Dasar dalam konteks ini, bisa dididik sehingga menyadari pentingnya bersikap arif pada lingkungan, dalam pengertian mereka mampu merawat dan melestarikannya, sebagai bentuk taqarrub kepada Allah SWT.

Sederhananya, pada pendidikan agama Islam berwawasan lingkungan, tujuan pendidikan agama Islam harus mampu mengantarkan siswa pada sebuah pemahaman bahwa pemeliharaan dan pelestarian lingkungan merupakan bentuk usaha untuk taqarrub kepada Allah. Hal ini karena kewajiban dan mengemban tanggung jawab untuk merawat dan melestarikan lingkungan juga merupakan bentuk ibadah kepada Allah SWT.

Menurut Sofan dan Lif Khoiru Ahmadi, materi atau bahan ajar adalah segala bentuk materi atau bahan yang digunakan untuk membantu guru dalam melaksanakan kegiatan belajar mengajar di kelas. Materi atau bahan ajar yang dimaksud dapat berupa bahan tertulis maupun bahan tidak tertulis. Materi atau bahan ajar kaitannya dalam pendidikan agama Islam berwawasan kearifan

\footnotetext{
${ }^{46}$ Ramayulis and Samsul Nizar, Filsafat Pendidikan Islam: Telaah Sistem Pendidikan dan Pemikiran Para Tokohnya, (Jakarta: Kalam Mulia, 2009), hlm. 273.

${ }^{47}$ Kurniawan, 'Pendidikan Menurut.......

${ }^{48}$ Departemen Agama RI, Al-Qur'an dan Terjemahan.
} 
lingkungan berarti seperangkat materi yang disusun secara sistematis baik tertulis maupun tidak, sehingga tercipta lingkungan atau suasana yang memungkinkan siswa untuk belajar tentang lingkungan dan memiliki kearifan lingkungan saat dan setelah materi diberikan. ${ }^{49}$

Materi atau bahan ajar dalam konteks ini berisi materi pembelajaran (instructional materials) yang secara garis besar terdiri dari pengetahuan, keterampilan, dan sikap yang harus dipelajari siswa dalam rangka mencapai standar kompetensi yang telah ditentukan. Secara terperinci, jenis-jenis bahan atau materi ajar Pendidikan Agama Islam terdiri dari pengetahuan (fakta, konsep, prinsip, prosedur), keterampilan, sikap dan nilai-nilai yang mencerminkan kearifan lingkungan.

Ditinjau dari pihak guru, materi atau bahan ajar Pendidikan Agama Islam ini perlu diajarkan atau disampaikan dalam kegiatan pembelajaran. Sementara ditinjau dari pihak siswa, materi atau bahan ajar itu harus dipelajari mereka dalam rangka mencapai standar kompetensi dan kompetensi dasar yang akan dinilai dengan menggunakan instrumen penilaian yang disusun berdasarkan indikator pencapaian belajar, yang sejalan dengan maksud membuat mereka, arif pada lingkungan.

Dalam konteks penguatan kearifan lingkungan pada siswa di Sekolah Dasar, di antara materi atau bahan ajar Pendidikan Agama Islam yang dapat diberikan pada siswa misalnya tentang fiqih lingkungan. Seperti dimafhumi, pada pelajaran fikih yang diberikan seringkali lebih banyak menyinggung tentang hubungan manusia dengan Tuhan (hablum minallah) dan persoalan relasi sesama manusia (hablum minannas). Masih sangat sedikit kajian fikih yang secara khusus berbicara mengenai pola hubungan manusia dengan alam (lingkungan).

Kecuali fiqh, materi tentang aqidah dan akhlaq juga bisa menyisipkan nilai-nilai cinta lingkungan, seperti materi tentang taubat. Ada dua model taubat yang umum dipahami dalam Islam. Pertama, bagi individu yang melakukan kesalahan atau perbuatan dosa yang sifatnya pribadi, maka model taubat yang diajarkan yaitu dia memohon ampun secara langsung kepada Tuhan dengan niat tulus untuk tidak mengulanginya lagi. Pada tingkatan ini, model taubatnya cenderung sederhana,

${ }^{49}$ Sofan dan Lif Khoiru Ahmadi, Kontruksi Pengembangan Pembelajaran, (Jakarta: Pustaka, 2010), hlm. 159 . 
karena hanya berorientasi vertikal kepada Tuhan. Kedua, menyangkut kesalahan atau dosa seorang individu yang melibatkan individu atau manusia yang lain seperti perbuatan dzalim atau utang piutang. Terhadap dosa atau pelanggaran yang melibatkan manusia lain atau lazim disebut dosa sosial, para ulama umumnya bersepakat bahwa taubat vertikal saja tidak cukup. Pada tingkatan ini, taubat vertikal dengan Tuhan dan kemaafan horizontal dari manusia lain harus berjalan seiring.

Sebenarnya, selain kedua model taubat di atas, kaitannya dalam hubungan manusia dengan alam, penting juga diperkenalkan model taubat khusus, dan ini kiranya menempati tingkatan ketiga. Manusia yang berbuat dosa atau kesalahan pada alam atau lingkungan, seperti merusak atau mengganggu keseimbangan alam, maka cara taubatnya tidak cukup hanya dengan media vertikal kepada Tuhan atau permakluman pada manusia. Karena alam yang dicederai, maka ridha dari alam harus terlebih dahulu diperoleh. Caranya dengan memulihkan kerusakan yang telah dilakukan pada alam, baru kemudian memohon ampunan kepada Tuhan. Perbuatan dosa kepada alam, maka azab yang ditimpakan Tuhan berlaku secara umum, tanpa memandang apa seseorang terlibat atau malah tidak tahu sama sekali terhadap kerusakan alam yang telah terjadi. Menjaga alam dari kerusakan dapat ditetapkan sebagai fardhu kifayah, yang apabila tidak dilaksanakan, maka seluruh manusia yang ada pada wilayah itu akan mendapatkan balasan adzab yang sifatnya kolektif.

Sejauh ini kita sering menyebut istilah kesalehan individu dan kesalehan sosial. Kesalehan individu, yaitu gambaran mereka yang kualitas ibadah ritualnya bagus dan kesalehan sosial yaitu mereka yang yang berbakti pada masalah sosial kemasyarakatan. Maka kini perlu dikembangkan lagi satu model kesalehan, yaitu kesalehan lingkungan. Kesalehan ini melekat pada mereka yang dapat menjaga alam atau lingkungan dengan bagus, melaksanakan mandat Tuhan sebagai khalifahnya di muka bumi. Ketiga macam kesalehan ini idealnya terintegrasi pada diri seorang Muslim, dan seharusnya telah diberikan sejak dini pada siswa-siswa di Sekolah Dasar.

Kaitannya dengan proses belajar mengajar atau proses pembelajaran Pendidikan Agama Islam merupakan proses interaksi antara guru dan siswa dalam suatu pengajaran untuk mewujudkan orientasi pembelajaran yang telah direncanakan atau ditetapkan. Telah disebutkan bahwa orientasi pendidikan agama Islam 
berwawasan kearifan lingkungan adalah menguatkan kearifan lingkungan sehingga menjadi karakter siswa. Dalam konteks penguatan kearifan lingkungan melalui pelajaran Pendidikan Agama Islam di Sekolah Dasar, seorang guru dapat menggunakan berbagai metode dan berbagai variasinya. Di antara metode yang dapat digunakan oleh guru bervariasi, seperti metode ceramah (metode penyampaian materi ilmu pengetahuan kepada siswa yang melalui proses penyampaian secara lisan), tanya jawab (metode di mana seorang guru mengajukan pertanyaan kepada siswa, atau sebaliknya, yang dimaksudkan dapat merangsang siswa berpikir dan membimbingnya dalam mencapai kebenaran), metode diskusi (metode di mana guru mengajak siswa-siswanya untuk dapat bersama-sama memecahkan masalah melalui adu argumentasi atau pendapat), metode pemecahan masalah (merupakan cara memberikan pengertian dengan menstimulasi siswa untuk memperhatikan, menelaah, dan berpikir tentang sesuatu masalah, dan selanjutnya menganalisa masalah tersebut sebagai usaha untuk memecahkannya), metode kisah (metode pembelajaran yang digunakan dengan cara memberi cerita atau dongeng tentang figur-figur yang dapat disesuaikan dengan orientasi pembelajaran yang diinginkan, sehingga dapat menggugah hati nurani dan berusaha melakukan hal-hal yang baik), metode suri tauladan (metode di mana seorang guru menjadikan dirinya sebagai suri tauladan siswa-siswanya sejalan dengan orientasi pembelajaran).

Terakhir juga penting diperhatikan dalam pengimplementasian pendidikan agama Islam berwawasan lingkungan adalah evaluasi. Tujuan evaluasi pembelajaran Pendidikan Agama Islam antara lain: pertama, mengetahui kemampuan belajar siswa dalam pembelajaran Pendidikan Agama Islam, baik sebagai individu maupun sebagai anggota kelompok atau kelas, setelah ia mengikuti pendidikan dan pembelajaran dalam jangka waktu yang telah ditentukan; kedua, mengetahui tingkat efektivitas dan efisiensi berbagai komponen pembelajaran yang dipergunakan guru dalam jangka waktu tertentu (misalnya: perumusan materi atau bahan ajar Pendidikan Agama Islam, pemilihan metode pembelajaran, media ajar, sumber belajar, dan lain-lain; dan ketiga, menentukan tindak lanjut pembelajaran pendidikan agama Islam bagi siswa. ${ }^{50}$

50 Junaidi, Modul Pengembangan Evaluasi Pembelajaran PAI, (Jakarta: Direktorat Pendidikan Agama Islam Kementerian Agama Republik Indonesia, 2011). 
Sementara itu, fungsi evalusi pembelajaran Pendidikan Agama Islam: pertama, alat untuk mengetahui tercapai atau tidaknya tujuan pembelajaran Pendidikan Agama Islam. Dengan fungsi ini, maka evalusi harus mengacu pada rumusanrumusan tujuan pembelajaran sebagai penjabaran dari kompetensi mata pelajaran; kedua, sebagai umpan balik bagi perbaikan proses belajar mengajar. Perbaikan mungkin dilakukan dalam hal tujuan pembelajaran Pendidikan Agama Islam, kegiatan atau pengalaman belajar siswa, strategi pembelajaran Pendidikan Agama Islam yang digunakan guru, media pembelajaran Pendidikan Agama Islam, dan lainlain; keempat, dasar dalam menyusun laporan kemajuan belajar siswa kepada para orang tuanya. Dalam laporan tersebut dikemukakan kemampuan dan kecakapan belajar siswa dalam bentuk nilai-nilai prestasi yang dicapainya. ${ }^{51}$ Mengingat penguatan kearifan lingkungan di kalangan Siswa Sekolah Dasar diharapkan dapat terujud setelah siswa menerima pelajaran Pendidikan Agama Islam, maka evaluasi pembelajaran untuk mengukur keberhasilan pembelajaran menjadi sebuah keharusan.

\section{E. Kesimpulan}

Kita sudah sama-sama tahu bahwa, pemanfaatan sumber daya alam yang berlebihan dan merusak selama ini telah menimbulkan dampak negatif yang besar bagi manusia dan alam itu sendiri. Rusaknya hutan, bencana banjir, tercemarnya air, tanah dan udara. Semua itu merupakan contoh nyata dari hasil pemanfaatan sumberdaya alam yang berlebih-lebihan. Allah SWT memang melarang kita berlebihlebihan dalam memanfaatkan alam dan apalagi merusak. “... Sesungguhnya Allah tidak menyukai orang-orang yang berlebih-lebihan." (QS. Al- A'raf [07]: 31); “Dan janganlah kamu membuat kerusakan di muka bumi, sesudah (Allah) memperbaikinya dan berdoalah kepadaNya dengan rasa takut (tidak akan diterima) dan harapan (akan dikabulkan). Sesungguhnya rahmat Allah amat dekat kepada orang-orang yang berbuat baik." (QS. Al-A'raf [07]: 56)

Dalam pandangan Islam, manusia adalah bagian dari alam, pengelola, dan khalifah (wakil Tuhan) di muka bumi. Sebagai khalifah di muka bumi, manusia tentu saja berhak memanfaatkan fungsi-fungsi alam. Tapi sebaliknya, manusia juga 
memiliki kewajiban dan mengemban tanggung jawab dari Tuhannya untuk merawat dan melestarikan alam (lingkungan), bukan justru mengambil langkah-langkah merusak dalam memanfaatkan sumber daya alam dari lingkungannya. Ringkasnya, agama Islam mengharamkan sikap-sikap merusak dalam memanfaatkan sumber daya alam yang tersedia dalam lingkungan dan mengakui pentingnya merawat dan melestarikan alam (lingkungan).

Jika kita menyetujui bahwa manusia dan pemikirannya adalah produk dari suatu proses pendidikan yang ia dapat, maka dapat dikatakan bahwa sifat dan perilaku manusia yang merusak lingkungan disebabkan karena pendidikan yang diterimanya tidak memaksimalkan usaha penguatan kearifan lingkungan. Karena itulah pelajaran Pendidikan Agama Islam seharusnya dapat secara optimal diberikan sejak dini pada anak-anak, seperti pada anak-anak usia sekolah dasar. Pendidikan Agama Islam berwawasan lingkungan perlu diberikan pada siswa seperti mengajarkan pada mereka tentang pentingnya merawat dan melestarikan lingkungan beserta fungsi-fungsinya.

Pelajaran Pendidikan Agama Islam yang diberikan pada siswa sejak dini ini akan berdampak positif mewujudkan hal tersebut, jika pelajaran Pendidikan Agama Islam memiliki desain yang baik untuk kepentingan tersebut. Setidaknya ada empat komponen yang mesti diperhatikan dalam pengimplementasiannya: pertama, tujuan pembelajaran; kedua, materi atau bahan ajar; ketiga, metode mengajar; dan keempat, evaluasi pembelajaran. Kesemua komponen ini mesti dipertimbangkan dalam merumuskan model kurikulum yang tepat dan penyediaan sarana prasarana yang mendukung. Harapannya setelah siswa menerima pelajaran pendidikan agama Islam, siswa mengalami perubahan, seperti menjadi lebih arif pada lingkungannya.

\section{DAFTAR PUSTAKA}

Albar, Mawi Khusni, "Pendidikan Ekologi Sosial dalam Perspektif Pendidikan Islam: Jawaban Terhadap Krisis Kesadaran Ekologis", dalam At-Tahrir, Vol. 17, No. 2, 2017. 
Baiquni, hmad, "Tugas Ganda Manusia", dalam Iqra', Yogyakarta: Salahuddin Press, 1985.

Dawud, Al-Imam Al-Hafizh Abu Sulaiman Al-Asy'ats Al-Sijistani Abu, Sunan Abu Dawud, Vol. 1, Beirut: Dar al-Kutub Al-'Ilmiyyah, 1996.

Departemen Agama RI, Al-Qur'an dan Terjemahan, Bandung: Diponegoro, 2010.

Julaeha, Eha dan Asep Kurniawan, "Implementasi Pendidikan Agama Islam (PAI) Berwawasan Lingkungan di Sekolah Menengah Kejuruan Negeri I Indramayu", dalam Al-Tarbawi al-Haditsah, Vol. 3, No. 2, 2018.

Junaidi, Modul Pengembangan Evaluasi Pembelajaran PAI, Jakarta: Direktorat Pendidikan Agama Islam Kementerian Agama Republik Indonesia, 2011.

Koran Sindo, "Survei Litbang Korban Sindo: 10 Problem Besar Lingkungan di Indonesia", Koran Sindo, Jakarta, Mei 2018, https://nasional.sindonews.com/read/1302781/15/10-problem-besarlingkungan-di-indonesia-1525347778.

Kurniawan, Syamsul, "Tanah Airku Murka: Pentingnya Membangun Kesadaran Ekoteologi", Pontianak Post, Pontianak, Nopember 2006.

Kurniawan, Syamsul, "Al-Qur'an dan Kesalehan Lingkungan", Pontianak Post, Pontianak, Oktober 2007.

Kurniawan, Syamsul, "Pendidikan Menurut Al-Ghazali", dalam At-Turats, Vol. 3, No. $1,2008$.

Kurniawan, Syamsul, Pendidikan Karakter: Konsepsi \& Implementasinya Secara Terpadu di Lingkungan Keluarga, Sekolah, Perguruan Tinggi dan Masyarakat, Yogyakarta: ArRuzz Media, 2013.

Ramdhani, Jabbar, "513 Bencana Alam Terjadi di Indonesia Sejak Januari-Maret 2018", Detik News, 3 Mar 2018, https:/ / news.detik.com/berita/3895731/513-bencanaalam-terjadi-di-indonesia-sejak-januari-maret-2018. 
Ramayulis and Samsul Nizar, Filsafat Pendidikan Islam: Telaah Sistem Pendidikan dan Pemikiran Para Tokohnya, Jakarta: Kalam Mulia, 2009.

Rustam, "Integrasi Pendidikan Karakter dalam Pendidikan Islam", dalam At-Turats, Vol. 6, No. 1, 2012.

Sofan dan Lif Khoiru Ahmadi, Kontruksi Pengembangan Pembelajaran, Jakarta: Pustaka, 2010.

Saidi, Zaim, "Islam Tradisional dn Krisis Lingkungan: Pandangan Seorang Aktifis", dalam Islamica, No. 3, 1994.

Usmar, Ali, "Pendidikan Islam Berwawasan Lingkungan", dalam An-Nahdhah, Vol. 8, No. 1, 2014. 